\title{
Ludwig's Angina: An Update of Clinical Features and Management
}

\author{
Syed Hasan Imam Al-Masum', Ali Jacob Arsalan²
}

\begin{abstract}
Background \& objective: Ludwig's angina (LA) is a potentially life-threatening, rapidly spreading, bilateral cellulitis of the submandibular spaces in children. In the preantibiotic era, the airway obstruction was almost inevitable and case fatality rate was as high as $60 \%$. With the introduction of antibiotics in 1940 s the LA has become an uncommon disease. As such, many physicians have limited experience of it. But its early recognition and aggressive management still carries utmost importance to avoid life-threatening acute airway obstruction. Therefore, the present study was undertaken to update the physicians with clinical features and management of Ludwig's angina.

Methods: The present descriptive study was conducted in Bangladesh Institute of Child Health \& Dhaka Shisu Hospital, Sher-e-Bangla Nagar, Dhaka between January 2012 to December 2016. Having obtained approval from the Institutional Review Board of the Institute, we retrospectively analyzed the clinical course and management of Ludwig's angina. During the period a total of 27 patients' record were found available. Data were collected on demographic and clinical characteristics, causes and predisposing factors, investigations, complications developed and outcome of LA. Penicillin with or without additional anaerobic coverage with clindamycin or metronidazole were used as key patient management strategy. Steroid was given for faster recovery of the patients having airway compromise. Patients who did not recover with conservative treatment underwent surgical treatment with incision and drainage.

Result: In the present study children with Ludwig's angina presented with bilateral swelling of the neck and submandibular region accompanied by pain and induration in the affected region. Systemic symptoms, such as, fever and malaise were also frequently present. Two-thirds $(66 \%)$ of the children had dehydration and almost half $(48 \%)$ had toxic look. Over one-third $(37 \%)$ of the children exhibited, restricted backward and upward elevation of tongue and over half with trismus. Of the systemic signs, high temperature, tachycardia, and tachypnoea were common presentation. One-third of the children exhibited signs of airway obstruction. Fifty percent of the children had the history of toothache (lower molar) one or two weeks prior to the development of Ludwig's angina, $40 \%$ had history of mumps and $3.7 \%$ had history of trauma to the mandible. Over one-quarter developed pneumonia with mediastinitis. Airway obstruction, manifested as unable to swallow saliva, dyspnoea, stridor and cyanosis, was exhibited by over $55 \%$ of the children and received intravenous steroid for faster recovery from the condition. More than three-quarters $(77.7 \%)$ of the patients responded to Penicillin with or without clindamycin or metronidazole and those who did not respond to it (22.3\%) underwent operative treatment.

Conclusion: Despite modern medical and surgical interventions have improved the outcomes of Ludwig's angina to a great extent, it still remains a potentially lethal disease in the pediatric population. Early recognition of the disease with identification of airway obstruction and prompt intravenous antibiotic therapy could resolve the disease without any complications or need for surgical intervention.
\end{abstract}

Key words: Ludwig's Angina, Clinical Features and Management etc.

\section{INTRODUCTION:}

Ludwig's angina (LA) is a potentially lethal, rapidly spreading cellulitis of the floor of mouth and neck. It was first described by German physician Wilhelm Fredrick von Ludwig in 1836. In the preantibiotic era, the rapid expansion and displacement of the anatomical structures of the oral cavity and oropharynx resulting from this infection could not be effectively prevented. The airway obstruction was the most frequent outcome of the disease, with

\section{Authors' information:}

${ }^{2}$ Dr. Syed Hasan Imam Al-Masum, Associate Professor, ENT Department, Dhaka Shisu Hospital, Sher-e-Bangla Nagar, Dhaka.

${ }^{2}$ Dr. Ali Jacob Arsalan, Resident Medical Officer, ENT Department, Dhaka Shisu Hospital, Sher-e-Bangla Nagar, Dhaka.

Correspondence: Dr. Syed Hasan Imam Al-Masum, Cell Phone: +8801711-141543, E-mail:shmasum_ent@yahoo.com 
fatality rates as high as $54 \%$ to $60 \% .^{1}$ This rate has significantly been reduced since the 1940 s with the

introduction of antibiotics, the improvement of oral and dental hygiene, and the aggressive surgical approaches. $^{2}$

Ludwig's angina involves bilateral sublingual, submandibular and submental spaces. It is characterized as a brawny swelling and induration in the submandibular region and elevation of the tongue and floor of the mouth with high fever and tachycardia. The primary site of infection in LA is submandibular space. The tongue becomes massively swollen, immobile \& displaced superiorly against the palate and posteriorly into hypopharynx, which results in airway compromise and puts the patient in danger of respiratory obstruction. ${ }^{3}$ Airway obstruction may occur through posterior and superior displacement of oral structures of the pharynx. ${ }^{4}$ Pre-existing acute dental infections in the form of abscesses, post-extraction sepsis and pericoronitis are the most common causes. ${ }^{5}$ The predisposing factors are dental caries, recent dental extraction, immunosuppression, sickle cell anemia, oral mucosal lacerations, submandibular sialadenitis, and mandibular fractures. ${ }^{6}$ While odontogenic infection, especially of the $2^{\text {nd }}$ and $3^{\text {rd }}$ lower molar tooth is the most common cause in adults, ${ }^{7}$ the deep neck space infections subsequent to upper respiratory tract infection (URI) is the major cause in children. ${ }^{8}$

Early recognition \& prompt management of Ludwig's angina are, therefore, of paramount importance to avoid life-threatening acute airway obstruction. ${ }^{10}$ Early recognition mainly depends on recognition of its clinical presentation. As Ludwig's angina has now become uncommon in adults and children, many physicians have limited experience of it. Therefore, the present study was intended to update the physicians with clinical features of Ludwig's angina.

\section{METHODS:}

The present descriptive study was conducted in Bangladesh Institute of Child Health \& Dhaka Shisu Hospital, Sher-e-Bangla Nagar, Dhaka between January 2012 to December 2016. Having approval from the Institutional Review Board of the Institute, we retrospectively analyzed the clinical course and management of Ludwig's angina. During the period a total of 27 patients' record were found available. Data were collected on variables of interest (demographic characteristics of the presenting patients, causes and predisposing factors, clinical presentation, investigations, complications developed \& management outcome of LA) and were analyzed using descriptive statistics (frequency, percentage, mean and standard deviation about the mean).

\section{RESULT:}

Over $40 \%$ of the children with Ludwig's angina presented at $5-6$ years of age, $55.6 \%$ between $7-10$ years and only $1(3.7 \%)$ at the age of 12 years with mean age of the children being $7.1 \pm 1.7$ years. Males outnumbered females with male to female ratio being $11: 9$. Over half $(51.9 \%)$ came from the urban slums and the rest from urban non-slum areas. Nearly half $(48.1 \%)$ was poor and the rest $(51.9 \%)$ was lower middle class. The average duration of disease was 10 days (Table I). Over half $(51.9 \%)$ of the children had the history of toothache (lower molar) one or two weeks prior to the development of Ludwig's angina, 11(40.7\%) had history of mumps and $2(3.7 \%)$ history trauma to the mandible (Table II).

Children invariably presented with bilateral swelling of the neck and submandibular area with pain in the affected region and dysphagia.

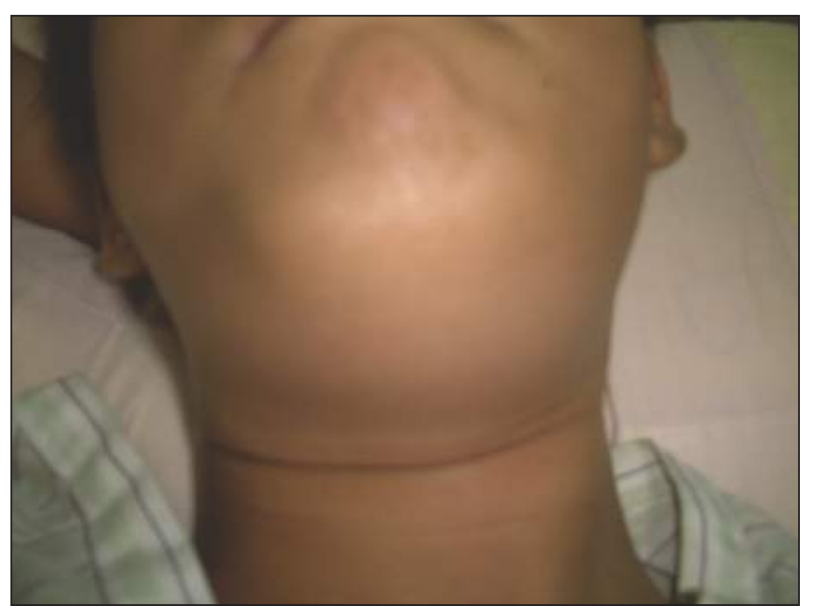

Fig. 1. Progressive submandibular neck swelling of a 14 year old boy. (Source:Adapted from Britt et al ${ }^{9} 2000$ ) 


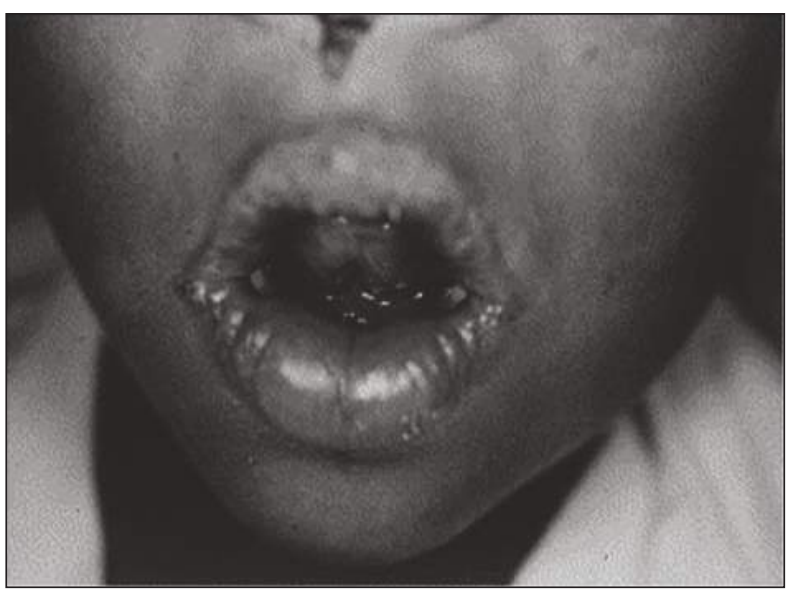

Fig. 2. Edema and induration of the floor of the mouth resulting in elevation of the tongue seen secondary to Ludwig's angina in a 5 year old boy (Source:Adapted from Britt et $\mathrm{al}^{9}$ 2000)

Systemic symptoms such as fever with or without chill and malaise were also present in all the children. Two-thirds (66.1\%) of the children had dehydration and nearly half (48.1\%) had toxic look (Table III). Local erythema with induration and severe tenderness were invariably present. Flactuation sign, restricted backward and upward elevation of

\begin{tabular}{|c|c|c|c|}
\hline \multicolumn{4}{|c|}{$\begin{array}{l}\text { TABLE I. Distribution of children by their demographic } \\
\text { characteristics }(n=27)\end{array}$} \\
\hline $\begin{array}{l}\text { Demographic } \\
\text { characteristics }\end{array}$ & Frequency & Percentage & $\begin{array}{l}\text { Mean } \pm S D \\
\text { (range) }\end{array}$ \\
\hline \multicolumn{4}{|l|}{ Age (years) } \\
\hline $5-6$ & 11 & 40.7 & \\
\hline $7-10$ & 15 & 55.6 & $7.1 \pm 1.7(5-12)$ \\
\hline$>10$ & 1 & 3.7 & \\
\hline \multicolumn{4}{|l|}{ Sex } \\
\hline Male & 15 & 55.6 & \\
\hline Female & 12 & 44.4 & \\
\hline \multicolumn{4}{|l|}{ Residence } \\
\hline Urban & 13 & 48.1 & \\
\hline Urban slum & 14 & 51.9 & \\
\hline \multicolumn{4}{|c|}{ Socioeconomic status } \\
\hline Poor & 13 & 48.1 & \\
\hline Lower middle & 14 & 51.9 & \\
\hline Disease duratic & & & $10.1 \pm 1.7(5-13)$ \\
\hline
\end{tabular}

TABLE II. Distribution of children by causes/factors of Ludwig's angina $(\mathbf{n}=27)$

\begin{tabular}{lcc} 
Causes or predisposing factors & Frequency & Percentage \\
\hline Toothache (lower molar) & 14 & 51.9 \\
Mumps & 11 & 40.7 \\
Trauma to the mandible & 2 & 7.4
\end{tabular}

TABLE III. Distribution of children by their clinical symptoms $(n=27)$

$\begin{array}{lcc}\begin{array}{l}\text { Clinical } \\ \text { presentation }\end{array} & \text { Frequency } & \text { Percentage } \\ \text { Focal symptoms } & & \\ \begin{array}{l}\text { Bilateral swelling of neck } \\ \text { \& submnadibular area }\end{array} & 27 & 100.0 \\ \text { Pain in the affected region } & 27 & 100.0 \\ \text { Dysphagia } & 27 & 100.0 \\ \text { Systemic symptoms } & 27 & 100.0 \\ \text { Fever with or without chill } & 27 & 100.0 \\ \text { Malaise } & 27 & 100.0 \\ \text { Dehydration } & 18 & 66.7 \\ \text { Toxic appearance } & 13 & 48.1\end{array}$

TABLE IV. Distribution of children by clinical signs $(n=27)$

$\begin{array}{lccc}\begin{array}{l}\text { Signs (examination } \\ \text { findings) }\end{array} & \text { Frequency } & \text { Percentage } & \begin{array}{c}\text { Mean } \pm \text { SD } \\ \text { (range) }\end{array} \\ \begin{array}{l}\text { Local } \\ \text { Local erythema }\end{array} & & & \\ \text { with induration } & 27 & 100.0 & \\ \begin{array}{l}\text { Severely tender to touch } \\ \text { Fluctuation }\end{array} & 27 & 100.0 & \\ \begin{array}{l}\text { Restricted backward and } \\ \text { upward elevation of tongue }\end{array} & 10 & 37.0 & \\ \begin{array}{l}\text { Systemic } \\ \text { Temperature ( } \geq 1030 \mathrm{~F})\end{array} & 17 & 62.9 & 102.5 \pm 1.24(100-104) \\ \begin{array}{l}\text { Tachycardia } \\ \text { (Pulse }>120 \text { beats/min) }\end{array} & 19 & 70.3 & 93.4 \pm 5.0(72-102) \\ \begin{array}{l}\text { Restricted mouth opening } \\ \text { (Trismus) }\end{array} & 15 & 55.5 & \\ \begin{array}{l}\text { Tachypnoea } \\ (>22 \text { breaths/min) }\end{array} & 16 & 59.2 & 22.0 \pm 4.0\end{array}$

TABLE V. Distribution of children by signs of airway obstruction $(n=27)$

$\begin{array}{lcc}\text { Signs of airway obstruction } & \text { Frequency } & \text { Percentage } \\ \text { Inability to swallow saliva } & 12 & 44.4 \\ \text { Dyspnoea } & 9 & 33.3 \\ \text { Stridor } & 4 & 14.8 \\ \text { Cyanosis } & 4 & 14.8\end{array}$

TABLE VI. Distribution of children by investigation findings $(\mathbf{n}=27)$

\begin{tabular}{lcc}
\hline Investigation findings & Mean \pm SD & Range \\
\hline $\begin{array}{l}\text { TC of WBC (cu-mm) } \\
\text { DC of WBC }\end{array}$ & $14878 \pm 3354$ & $9700-20000$ \\
Ploymorphonuclear leucocytes (\%) & $76.8 \pm 6.2$ & $(69-87)$ \\
Lymphocytes (\%) & $20.1 \pm 6.6$ & $(10-41)$ \\
Esinophil (\%) & $4.4 \pm 1.1$ & $(3-7)$ \\
Monocyte (\%) & $5.0 \pm 0.6$ & $(4-6)$ \\
Serum CRP $(\mathrm{mg} / \mathrm{dl})$ & $21.4 \pm 5.2$ & $(13-31)$
\end{tabular}


TABLE VII. Distribution of children by complications encountered ( $n=27)$

$\begin{array}{lcc}\text { Complications } & \text { Frequency } & \text { Percentage } \\ \text { Pneumonia } & 8 & 26.9 \\ \text { Mediastinitis } & 7 & 25.9\end{array}$

TABLE VIII. Distribution of children by complications encountered $(n=27)$

$\begin{array}{lcc}\text { Management } & \text { Frequency } & \text { Percentage } \\ \text { Conservative } & & \\ \text { Penicillin } & 27 & 100.0 \\ \text { Clindamycin } & 13 & 100.0 \\ \text { Metronidazole } & 27 & 100.0 \\ \text { Intravenous steroid } & 15 & 55.5 \\ \text { Operative } & & \\ \text { Surgical decompression, } & & \\ \text { incision and drainage } & 6 & 22.3 \\ \text { Tracheostomy } & 0 & 0.0\end{array}$

tongue and trismus were found in $25.9 \%, 37 \%$ and $55.5 \%$ cases respectively. Of the systemic signs, high temperature $\left(\geq 103^{\circ} \mathrm{F}\right)$, tachycardia, \& tachypnoea were present in $62.9 \%, 70.3 \%$, and $59.2 \%$ respectively (Table IV). In terms of signs of airway obstruction, $12(44.4 \%)$ children were unable to swallow saliva, one-third (33.3\%) was dyspnoeic, $14.8 \%$ had stridor and cyanosis (Table $\mathrm{V}$ ).

The mean WBC count was $14878 \pm 3354$ /cu-mm of blood with polymorphonuclear leucocytes being predominant $(76.8 \%)$. The mean serum CRP level was $21.4 \mathrm{mg} / \mathrm{dl}$ (range: 13-31 mg/dl) (Table VI). Over one-quarter of the children developed pneumonia (26.9\%) and mediastinitis (25.9\%). However, none of the children died of the disease (Table VII). Of the 27 patients, $21(77.7 \%)$ improved with conservative treatment (Penicillin combined with metronidazole and/or clindamycin). However, over half $(55.5 \%)$ of the patients required intravenous steroid for rapid relief from airway obstruction. The children who did not improve by conservative management (22.3\%) had to undergo operative treatment with incision and drainage (Table VIII).

\section{DISCUSSION:}

In the present study children with Ludwig's angina presented with bilateral swelling of the neck and submandibular region accompanied by pain and induration in the affected region. Systemic symptoms such as fever and malaise were also frequently present. Two-thirds (66\%) of the children had dehydration. Toxic appearance was also no less $(48 \%)$. Over one-third (37\%) of the children exhibited restricted backward and upward elevation of tongue \& over half was with trismus. Of the systemic signs, high temperature, tachycardia, \& tachypnoea were common presentation. Consistent with the findings of the present study Harrison \& associates. ${ }^{11}$ demonstrated that patients with Ludwig's angina classically present with a myriad of focal and systemic signs and symptoms. Focal symptoms may include pain in and around the submandibular region, dysphagia, trismus, dysphonia, \& drooling. These are often accompanied by local physical signs, such as, progressive bilateral submandibular and submental neck swelling, firm induration of the floor of the mouth, and edematous posterior and superior displacement of the tongue (Figure 1 \& 2). Frequently encountered systemic signs and symptoms include fever, chills, malaise, dehydration from decreased oral intake, and a generalized toxic ill-appearance which compare well with our findings.

The primary site of infection in LA is submandibular space. The tongue becomes massively swollen, immobile and displaced superiorly against the palate and posteriorly into hypopharynx, which results in airway compromise and puts the patient in danger of respiratory obstruction. ${ }^{12}$ The early signs and symptoms of obstruction, however, might be subtle. More insidious findings such as dyspnoea, cyanosis, and/or stridor imply impending airway obstruction and respiratory compromise..$^{13}$ In our study around one-third of the children exhibited signs of airway obstruction. The management of airway obstruction is challenging, particularly when it occurs in children. In children, the larynx is positioned relatively higher in the neck than in adults, and one does not have the option for blind nasal intubation or awake fiberoptic, which otherwise is the technique of choice in adult patients. ${ }^{14}$ For the pediatrician in the outpatient setting, the presence of firm oedema of the floor of the mouth or tongue in combination with pain and swelling of the neck 
just below the mandible should immediately raise suspicion for Ludwig's angina. These are the cardinal signs that may directly lead to airway obstruction. Airway compromise was the leading cause of death in the early 1900s, when two-thirds of patients with Ludwig's angina required anticipatory or emergent intubation..$^{15}$ Since 1943, antimicrobial therapy has reduced the frequency of airway intervention to $<50 \% .{ }^{16}$ The mortality rate has also been decreased dramatically in the pediatric population because of aggressive antibiotic therapy. ${ }^{9,17}$ So early recognition of Ludwig's angina is crucial for initiation of proper medical therapy and timely consultation for emergency and surgical treatment. A patient with Ludwig's angina should be primarily assessed for airway stability. Currently, airway observation is an important component in the care of pediatric patients due to the widespread reluctance for immediate airway intervention. In a retrospective review $^{17}, 10 \%$ of children with Ludwig's angina needed airway control, whereas $52 \%$ of patients $>15$ years of age underwent tracheostomy.

In the present study over $50 \%$ of the children had the history of toothache (lower molar) one or two weeks prior to the development of Ludwig's angina, $40 \%$ had history of mumps and $3.7 \%$ had history of trauma to the mandible. A periapical abscess, penetrating injuries of the mouth floor, otitis media, and oral neoplasms have been reported as potential causes of Ludwig's angina. ${ }^{9}$ Complications of Ludwig's angina include sepsis, pneumonia, asphyxia, empyema, pericarditis, mediastinitis, and pneumothorax. In our study over one-quarter of the patients developed pneumonia with mediastinitis. Early and aggressive antibiotic therapy must be instituted to eradicate both aerobes and anaerobes. Penicillin or a penicillin derivative, with or without additional anaerobic coverage with clindamycin or metronidazole, is frequently used. ${ }^{2,9,17,18,19}$ The same combinations of antibiotics were also applied in our study as conservative treatment (Penicillin combined with metronidazole and/or clindamycin) and more than three-quarters $(77.7 \%)$ of the patients responded to it. However, over 55\% of the patients required intravenous steroid for faster recovery from airway compromise. Intravenous steroids decrease oedema \& cellulitis, which helps maintain airway integrity, improves antibiotic penetration into the infected area, and reduces the length of hospital stay. ${ }^{19}$

The children who did not improve by conservative management $(22.3 \%)$ underwent operative treatment with incision and drainage. Surgical decompression of the cellulitis is reserved for cases that are unresponsive to medical therapy or for patients who show clinical evidence of localized abscess formation upon initial physical examination. ${ }^{9}$ Contrastenhanced CT imaging should be considered to assess the extent of the abscess and detect possible odontogenic etiology. ${ }^{20}$ However, we did not suggest it in any of the 6 cases who required surgical intervention. Finally, adequate nutrition \& hydration were provided to the patients with Ludwig's angina.

\section{CONCLUSION}

Despite modern medical and surgical interventions have improved the outcomes of Ludwig's angina to a great extent, it still remains a potentially lethal disease in the pediatric population. Early recognition of the disease is of utmost importance. Pediatricians and physicians should consider Ludwig's angina when patients present with symptoms such as oral cavity and neck swelling accompanied by pain and induration, even when no offending pathologies are immediately apparent. With early diagnosis, airway observation, management $\&$ aggressive intravenous antibiotic therapy, this disease should resolve without any complications or need for surgical interference.

\section{REFERENCES:}

1. Burke J. Angina ludovici: a translation, together with biography of Wilhelm F.V. Ludwig. Bull Hist Med 1939; 7:1115e1126.

2. Patterson HC, Kelly JH, Strome M. Ludwig's angina: an update. Laryngoscope 1982;92:370e377.

3. Kremer MJ, Blair T. Ludwig angina: Forewarned is forearmed. AANA J 2006;74:445-51.

4. Iwu CO. Ludwig's angina: report of seven cases and review of current concepts in management. $\mathrm{Br} \mathrm{J}$ Oral Maxillofac Surg 1990;28:189-93.

5. Tuffin JR. Ludwig's angina: an unusual sequel to endodontic therapy. Inter Endodont J 1989;22:142-7. 
6. Kulkarni AH, Pai SD, Bhattarai B, Rao ST, Ambareesha M. Ludwig's angina and airway considerations: A case report. Cases J 2008;1:19.

7. Kavarodi AM. Necrotizing fasciitis in association with Ludwig's angina - A case report. Saudi Dent J 2011;23: 157-60.

8. Lin HW, O'Neill A, Cunningham MJ. Ludwig's angina in the pediatric population. Clin Pediatr (Phila) 2009; 48:583-7.

9. Britt J, Josephson G, Gross C. Ludwig's angina in the pediatric population: report of a case and review of the literature. Int J Pediatr Otorhinolaryngol 2000;52(1): 79-87.

10. Kremer $\mathrm{MJ}$, Blair T. Ludwig angina: Forewarned is forearmed. AANA J 2006;74:445-51.

11. Harrison W. Lin HW, O'Neill A, Cunningham MJ. Ludwig's Angina in the Pediatric Population. Clinical Pediatrics 2009;48(6):583-87.Availableat:http://clp.sagepub. com

12. Kremer MJ, Blair T. Ludwig angina: Forewarned is forearmed. AANA J 2006;74:445-51.

13. Harrison W. Lin, Allison O'Neill, and Michael J. Cunningham Ludwig's Angina in the Pediatric Population. Clinical Pediatrics 2009;48(6):583-87. Available at: http://clp.sagepub.com).
14. Pandey M, Kaur M, Sanwal M, Jain A, Sinha SK. Ludwig's angina in children anesthesiologist's nightmare: Case series and review of literature. Journal of Anaesthesio/ogy Clinical Pharmacology 2017;33(3):406-09).

15. Har-El G, Aroesty JH, Shaha A, et al. Changing trends in deep neck abscess. A retrospective study of 110 patients. Oral Surg Oral Med Oral Pathol Oral Radiol Endod 1994;77:446e450.

16. Moreland LW, Corey J, McKenzie R. Ludwig's angina. Report of a case and review of the literature. Arch Intern Med 1988;148:461e466.

17. Kurien M, Mathew J, Job A, Zachariah N. Ludwig's angina. Clin Otolaryngol Allied Sci 1997;22:263e265.

18. Srirompotong $S$, Art-Smart T. Ludwig's angina: a clinical review. Eur Arch Otorhinolaryngol 2003;260:401e403.

19. Busch RF, Shah D. Ludwig's angina: improved treatment. Otolaryngol Head Neck Surg 1997;117: S172eS175.

20. Parhiscar A, Har-El G. Deep neck abscess: a retrospective review of 210 cases. Ann Otol Rhinol Laryngol 2001;110:1051e1054. 